\title{
Risk Information Disclosure of Vietnam Listed Banks
}

\author{
Ngo Thu GIANG ${ }^{* *}$ and Dang Anh TUAN ${ }^{2}$ \\ ${ }^{1}$ Department of Financial Management, School of Economics and Management, Hanoi University of Science \\ and Technology, Hanoi, Vietnam \\ ${ }^{2}$ Department of Monetary and Finance Theory, School of Banking and Finance, National Economics \\ University, Hanoi, Vietnam \\ ${ }^{*}$ Corresponding author: giang.ngothu@,hust.edu.vn
}

\begin{abstract}
Research purpose:

Basel Committee (2004) sets the Basel 2 with three pillars as Pillar 1 (Capital Adequacy Requirements) and Pillar 2 (Supervisory review) in order to improve bank efficiency. More specifically, the Pillar 1 with information disclosure requirement to support bank-related parties in financial market in assessing important information related to applying regulations of minimum capital adequacy ratio calculation involves risks, risk assessment process and banks' level of capital adequacy. The application of Basel II requires complicated data and analytical models, which might be challenging for banks in Vietnam where there are no consensus and common standards on operations as well as on statistical data. To improve banks' transparency and integration to the international standard, the Circular 41 has been issued to stipulate the minimum disclosure of information to be made by banks and foreign bank branches in Vietnam. This paper studies current risk information disclosure of Vietnam listed banks right under the stipulation of the Circular 41/TT-NHNN.
\end{abstract}

\section{Research motivation:}

The research has been done not only to evaluate the current risk disclosure of Vietnam banks but also to provide the foundations for proposing policy recommendations regarding the risk information disclosure of commercial banks in Vietnam.

\section{Research design, approach and method:}

Circular 41 stipulates the content of information published by banks and foreign bank branches in Vietnam. The current risk disclosure of Vietnam listed banks is evaluated basing on scoring method. Except for the information of the bank's name, which gets 1 point; for all other information item, the score is 2 for fully disclosing according to regulations, the score is 1 if non-detail disclosing and 0 for non-disclosing. The number of studied banks is 15 out of 19 listed banks in Vietnam Stock Exchange.

\section{Main findings:}

The study results indicate that the disclosure compliance of listed banks is good when the Circular 41 is implemented. The detailed information disclosure group (over 45 points) includes 9 banks, the medium disclosure group (18-22 points) includes 4 banks, and the last group includes 2 banks with no information. The average disclosure banks tend to have less detail on market risk and operational risk than the detailed information disclosure group

\section{Practical/managerial implications:}

The banks should put disclosure information that meets Circular 41 in a separate section on the website to make it easier for investors to find and access. In addition, Circular 41 and Circular 13/2018/TT-NHNN have given full guidelines for commercial banks to apply Basel II and this is still a challenge for many banks while the Basel Committee introduced the Basel III version. Some domestic banks have also taken steps to prepare for the application of this Basel III standard. Thus, in order to support banks in Vietnam to continue implementing Basel III, the State Bank of Vietnam needs to provide guidance and support for commercial banks to implement this activity.

Keywords: CAR, credit risk, Basel II, information disclosure, commercial bank 


\section{INTRODUCTION}

Market discipline - information disclosure requirement is the Pillar 3 of Basel 2 with the purpose of improving efficiency of the Pillar 1 (Capital Adequacy Requirements) and Pillar 2 (Supervisory review). Basel Committee (2004) sets information disclosure requirement to support bank-related parties in financial market in assessing important information related to applying regulations of minimum capital adequacy ratio calculation, involved risks, risk assessment process and banks' level of capital adequacy.

The Basel II Accord was announced in 2004 to improve the quality and stability of the international banking system, which took effect from January 2007 and banks have a transition period until the end of 2010. The Basel II framework is created on three main pillars: (i) the minimum capital adequacy ratio of $8 \%$ which has not be changed compared to Basel I, but the calculation of capital requirements for credit risk has undergone major changes, along with changes in the calculation of operational risk. market dynamics and risks; (ii) the bank's internal risk monitoring process; (iii) marketbased disclosure recommendations on capital structure, capital adequacy, credit risk, operational risk and assessment process for each of these risks.

The application of Basel II requires complicated data and analytical models, which poses many challenges for banks in Vietnam when there are no consensus and common standards on operations as well as on statistical data. According to JICA, Asian countries applied Basel II in the period from 2008-2010. For commercial banks in Vietnam, applying Basel II is an indispensable requirement in the context of deepening international economic development and integration.

For Pillar I, according to the provisions of Circular No. 41/2016/TT-NHNN (Circular 41) from January 1, 2020, banks will have to officially apply the capital adequacy ratio according to the standards of Basel II. Appendix 5 promulgated together with Circular 41 stipulates the minimum disclosure of information to be made by banks and foreign bank branches in relation to capital adequacy ratio and related risks.

Within the scope of this study, the risk information disclosure activities of commercial banks complying with the regulations on information disclosure in Circular 41 are evaluated. The study also proposes policy recommendations regarding to risk information disclosure of commercial banks in Vietnam.

\section{DISCLOSURE OF RISK INFORMATION IN ACCORDANCE WITH CIRCULAR 41 AND MEASUREMENT METHODS}

In principle, the bank's risk disclosure must be consistent with the risk assessment and management activities of the bank's board of directors. Under Pillar 1, banks use comprehensive methods to assess different types of risk in order to determine minimum capital requirements. With this approach, the Basel Committee is expected to provide a common platform for banks to disclose information to the market, helping market participants to assess the risks faced by banks. and can compare the risks among banks. Banks are proposed to disclose information semiannually. Large banks must disclose information on tier 1 capital, aggregate capital adequacy ratios and individual capital adequacy ratios on a quarterly basis.

For confidential and proprietary information, if disclosure may affect the bank's operations or competitive position, the bank does not need to disclose specifically but generally and explains the reason of non detail disclosure behavior. This provision does not conflict with specific disclosure requirements in modern accounting standards.

Circular 41 (Appendix 5) stipulates the minimum content of information published by banks and foreign bank branches. The requirements are reflected in Table 1 . 
Table 1. Risk information disclosure (RID) requirements under Circular 41

\begin{tabular}{|c|c|}
\hline Items & RID score \\
\hline Organization Name & 1 \\
\hline Scope of measurement of capital adequacy ratio & \\
\hline $\begin{array}{l}\text { Qualitative content: The list of subsidiaries, associates and companies which are exempted } \\
\text { from calculation of consolidated capital adequacy (e.g. insurance subsidiaries), which clearly defines } \\
\text { the entities that are fully consolidated, pro-rate consolidated and not consolidated under regulations } \\
\text { on financial statements applied to credit institutions and foreign bank branches. } \\
\text { (b) Quantitative content: The aggregate amount of investment in insurance subsidiaries which } \\
\text { is not included in the consolidation upon calculation of consolidated capital adequacy ratio }\end{array}$ & 2 \\
\hline Equity capital structure & \\
\hline $\begin{array}{l}\text { Qualitative disclosures: Summary information on the maturity, terms and conditions of all } \\
\text { equity capital instruments of banks and foreign bank branches. } \\
\text { (b) Quantitative disclosures: } \\
\text { - The amount of Tier } 1 \text { and consolidated Tier } 1 \text { capital; } \\
\text { - The total amount of Tier } 2 \text { and consolidated Tier } 2 \text { capital; } \\
\text { - The total amount of other deductions from calculation of equity capital and consolidated equity } \\
\text { capital. }\end{array}$ & $\begin{array}{l}2 \\
2 \\
2\end{array}$ \\
\hline Capital adequacy ratio & \\
\hline $\begin{array}{l}\text { a) Qualitative disclosures: A description of the bank's capital strategy and the approach to } \\
\text { assessing the capital adequacy ratio to ensure maintenance of the capital adequacy ratio required. } \\
\text { b) Quantitative disclosures: } \\
\text { - Capital adequacy disclosure: Capital adequacy ratio, consolidated capital adequacy ratio (if any), } \\
\text { Tier } 1 \text { capital adequacy ratio, consolidated Tier } 1 \text { capital adequacy ratio (if any); } \\
\text { - Risk-weighted assets for credit risk (including credit exposure and counterparty credit risk); } \\
\text { - Capital requirements for market risk; } \\
\text { - Capital requirements for operational risk. }\end{array}$ & $\begin{array}{l}2 \\
2 \\
2\end{array}$ \\
\hline 4. Credit risk: & \\
\hline $\begin{array}{l}\text { a) Qualitative disclosures: } \\
\text { - A summary discussion of risk management policies; } \\
\text { - The list of rating agencies used for the purpose of assessing the capital adequacy ratio (if any); }\end{array}$ & $\begin{array}{l}2 \\
2\end{array}$ \\
\hline
\end{tabular}


- The list of collateral and third-party guarantees, on-balance sheet netting and credit derivatives eligible for being recognized as credit risk mitigation;

b) Quantitative disclosures:

- Receivables, rating-specific risk weights and total risk-weighted asset for credit exposure for which rating agencies are used;

- Risk-weighted assets for credit risk exposure and counterparty credit exposure, broken down by subjects having credit weights as prescribed by Article 9 of this Circular;

- Risk-weighted assets for credit risk, broken down by industry sector;

- Risk-weighted assets for credit risk exposure (including on-balance and off-balance sheet) before and after the effect of credit risk mitigations referred to Article 11 of this Circular.

\section{Operational risk:}

a) Qualitative disclosures:

- A summary discussion of operational risk management policies;

- A summary of the strategy for maintenance of continuous operations (if any).

b) Quantitative disclosures:

- Business indicators and business indicator components such as IC, SC and FC referred to in Article 16 of this Circular;

- Capital requirements for operational risk.

\section{Market risk:}

a) Qualitative disclosures:

- A summary description of market risk management policies;

- A summary discussion of the proprietary trading strategy;

- List of exposures in the trading book.

b) Quantitative disclosures:

Capital requirements for market risk, including interest rate risk, equity position risk, commodity risk, foreign exchange risk and options positions.

Total

\section{Source: Circular 41/2016/TT-NHNN}

Comparing regulations on information disclosure between Circular 41 and Basel II, there are many remarkable differences. In which, Basel II focuses detailly on the methods of calculating risky assets (by 3 methods) and derivatives, while Circular 41 does not require a distinction between these 3 methods. This difference comes from one of the reasons that Basel II is recommended to be applied to countries with highly developed financial markets and financial systems (derivatives, asset securitizations), while these markets in Vietnam have not yet developed. 


\section{MEASUREMENT METHODS OF BANKS' RISK INFORMATION DISCLOSURE}

Baumann and Nier (2003) is one of the pioneering researchers to build a set of indicators to evaluate information disclosure in banks. The aggregate disclosure index is built from three indicators: (1) The index reflects a bank listed on a stock exchange such as the NYSE, NASDAQ or AMEX. (2) The second index is based on the bank's rating by a credit rating agency; (3) The third index is built on 18 important information items provided in the bank's annual financial statements and saved in Bank scope's database. These information items are relevant to one or several aspects of banking risks (interest rate risk, credit risk, liquidity risk and market risk).

The bank disclosure index proposed by Huang (2006) includes two sets of indicators: the core set of indicators and the advanced set of indicators. These two sets of indexes are created based on the one proposed by Erlend Nier (Bank of England). Disclosure index is synthesized from 6 groups of publicly available information, including: (1) Credit: analysis of loans at maturity, type, counterparty, credit risk, for questionable loans. title,,. (2) Other profitable assets: securities by type and purpose of holding; (3) Deposits: dividing deposits by term, type of customer; (4) Other financing: money market financing and other long-term financing; (5) Capital and reserves: disclose the ratio of capital, reserves, contingent liabilities, off-balance sheet,... (6) Income: non-interest income and provisions for loan risks. This approach scores information on 17 published core information items. These core information items have a high similarity with the disclosure criteria of the Basel Committee and the Financial Soundness Indicators System (FSIs) of the International Monetary Fund.

In this study, the authors scored risk information disclosure based on the amount of information on capital adequacy ratio, credit risk, market risk and operational risk as required in the Circular 41 of Vietnam State Bank; and mentioned detailly in the Table 1. For each scoring criterion in Table 1 (except for the criterion of the bank's name, which gets 1 point), the score is 2 for fully disclosed information according to regulations, the score is 1 if there is disclosure of information about the bank. criteria but not detailed and specific and 0 for nondisclosing (Score column in Table 1). The highest score of the Bank's Risk Disclosure Index according to the scoring method is 53 .

\section{STATUS OF RISK INFORMATION DISCLOSURE OF COMMERCIAL BANKS IN VIETNAM}

Data reflecting current risk information disclosure of Vietnam commercial banks is collected with the sample of 19 banks listed in Hanoi and Ho Chi Minh city Stock Exchanges as of March 31, 2021. The list of banks is shown in Appendix 1.

Even enforceable effect date of the Circular 41 has been regulated as 01 January 2020, however, not all the banks have complied stricly the Circular. Vietnam Joint Stock Commercial Bank for Industry and Trade announced the application of Circular 41 from January 1, 2021 (Duy Lap, 2020). Regarding risk disclosure of other three banks, namely North Asia Commercial Joint Stock Bank (first listing date 3/3/3031), Saigon Thuong Tin Commercial Joint Stock Bank, and National Citizen Commercial Joint Stock Bank; the study team did not find out the information disclosure related to the Circular 41. Hence, the study sample includes 15 listed banks.

Circular 41 takes effect from January 1, 2020, and in order to evaluate the disclosure of risk information every 6 months/year according to the financial year (Article 20, Clause 1), the authors have collected all the available risk disclosure reports as at December 31, 2019, June 30, 2020 and December 31, 2020 in the period from December 2019 to December 2020; and scored. This risk disclosure reports are collected from the bank's website, HoChiMinh stock exchange and HaNoi Stock exchange.

Scoring results and statistics from 15 listed banks show the following key results:

a. The average score on disclosure increased significantly from the end of 2019 to the middle of 2020 and the end of 2020. This shows that the disclosure compliance of listed banks is good when the Circular 41 
comes into force (Table 2). At the end of 2019, only risk disclosure data of 8/15 listed banks were collected while by the middle and the end of 2020, 13 banks, 13 listed banks have disclosed.

b. It is noteworthy that the research team was not able to collect data on information disclosure of Orient Commercial Joint Stock Bank (OCB) in the year 2020, and Southeast Asia Commercial Joint Stock Bank in the end of 2020. Average score of information disclosure of 15 banks at the end of 2020 increased compared to the middle of the year (and the difference of information disclosure at the end of 2019 and 2020 was shown statistically and significantly in table 3 ).

Table 2 Descriptive statistics on risk disclosure scores of listed banks

\begin{tabular}{|c|c|r|r|r|}
\hline ID Time & No of Banks & \multicolumn{1}{|c|}{$\begin{array}{c}\text { Average ID } \\
\text { score }\end{array}$} & Lowest ID score & Highest ID score \\
\hline $12 / 2020$ & 15 & 40.1 & 0 & 53 \\
\hline $6 / 2020$ & 15 & 38.0 & 0 & 53 \\
\hline $12 / 2019$ & 15 & 22.8 & 0 & 53 \\
\hline
\end{tabular}

Source: Study Team, 2021

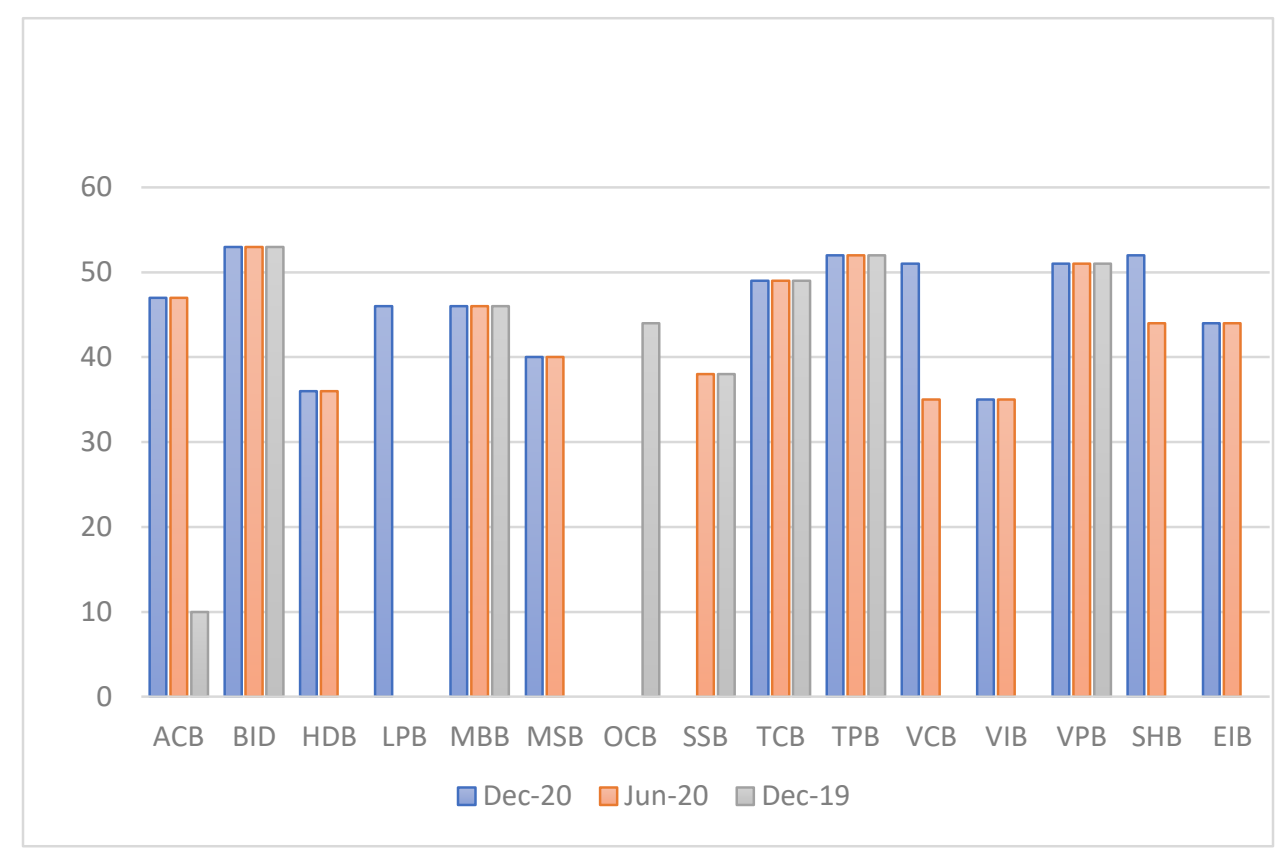

Figure 1 Risk information disclosure in compliance with the Circular 41

The figure 1 show current status of risk information disclosure of the listed banks at December 2019, Middle of 2020 and December of 2020. BID has best and sustainable risk information disclosure. The second best banks are MBB, TBP, TCB and VPB. The figure also

Source: Study Team, 2021

show that the risk information disclosure of the listed banks have been positively changed immediate right after the Circular 41 in effective. Hence, regarding the comparison of information disclosure scores between banks with published data in 2020, banks can be divided into 3 groups by ID performance. The detailed 
information disclosure group (over 45 points) includes 9 banks, the medium disclosure group (18-22 points) includes 4 banks, the last group include 2 banks with no information (Figure 1).

Regarding to disclosure level among information categories, as mentioned in measurement method, the risk disclosure is classified into 6 main categories as Scope of measurement of capital adequacy ratio (CARCAL), Equity capital structure (OE), Capital adequacy ratio (CAR), Credit risk (CRERISK), Operational risk (OPERISK) and Market risk (MKRISK). The risk information disclosure of studied banks are shown in Figure 2. The figure shows the percentage of disclosure in comparison with the regulation. The study team found that the average disclosure banks tend to have less detail on market risk and operational risk than the detailed ID group.

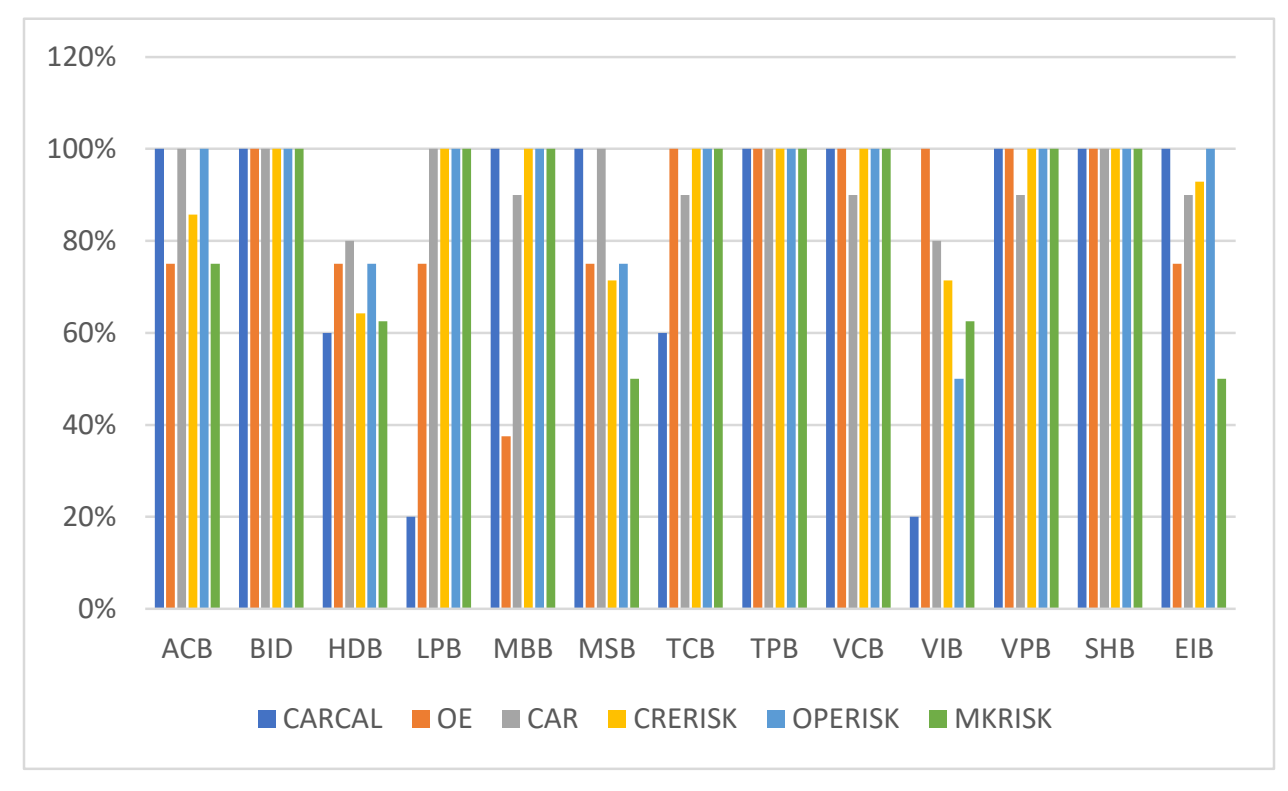

Figure 2 Risk information disclosure in categories

Source: Study Team, 2021

The research team has tested difference in risk information disclosure of banks at the end of 2019 and end of 2020. The result is shown in table 3. With $p$ value of 0.001 , it is confidentiality conclude that the risk information disclosure has changed significantly with confidence interval of $100 \%$. The banks comply strictly to regulations of the authority.

Table 3 Comparison of ID scores in June 2020 and December 2019 in compliance with the Circular 41

\begin{tabular}{|c|c|c|c|c|c|c|c|c|c|c|}
\hline \multicolumn{11}{|c|}{ Independent Samples Test } \\
\hline & & \multicolumn{2}{|c|}{$\begin{array}{l}\text { Levene's Test for Equality of } \\
\text { Variances }\end{array}$} & \multicolumn{7}{|c|}{ t-test for Equality of Means } \\
\hline & & \multirow[b]{2}{*}{$\mathrm{F}$} & \multirow[b]{2}{*}{ Sig. } & \multirow[b]{2}{*}{$t$} & \multirow[b]{2}{*}{ df } & \multirow[b]{2}{*}{ Sig. (2-tailed) } & \multirow{2}{*}{$\begin{array}{c}\text { Mean } \\
\text { Difference }\end{array}$} & \multirow{2}{*}{$\begin{array}{l}\text { Std. Error } \\
\text { Difference }\end{array}$} & \multicolumn{2}{|c|}{$\begin{array}{l}95 \% \text { Confidence Interval of the } \\
\text { Difference }\end{array}$} \\
\hline & & & & & & & & & Lower & Upper \\
\hline \multirow[t]{2}{*}{ CBTT41 } & $\begin{array}{l}\text { Equal variances } \\
\text { assumed }\end{array}$ & \multirow[t]{2}{*}{13.105} & \multirow[t]{2}{*}{.001} & 1.993 & 28 & .056 & 15.13333 & 7.59377 & -.42181 & 30.68847 \\
\hline & $\begin{array}{l}\text { Equal variances not } \\
\text { assumed }\end{array}$ & & & 1.993 & 24.701 & .057 & 15.13333 & 7.59377 & -.51595 & 30.78261 \\
\hline
\end{tabular}

In order to update the information disclosure of listed banks by mid-2021 (according to the regulation on ID at every 6 months of Circular 41), the research team conducted an examination of the company website's information disclosure on liquidity risk and operation risk of 15 listed banks (Module of Information section 
for shareholders/Disclosure) during the period 24$25 / 8 / 2021$, the research team found that there were 4 banks that made the announcement. information on capital adequacy, operational risk, and liquidity risk in the first 6 months of 2021. Many banks (7) made risk information disclosure for the end of 2020 in the months

From the results of data synthesis and analysis, the research team believes that Circular 41 has had a positive impact on the disclosure of capital adequacy, market risk and operational risk of listed banks. In addition to the mandatory disclosure of financial information for listed organizations, disclosure of information on operation risk and market risk is important financial information for investors to consider.

Although the initial results were relatively optimistic, the analysis results showed that the information disclosure activities of capital adequacy, operating risk, and market risk were uneven and unsustainable in some banks. This may explain that banks are not interested in disclosing information to investors or information disclosure is not effective.

\section{CONCLUSION AND RECOMMENDATION}

This is one of the very few studies in Vietnam that are interested in the disclosure of commercial bank information. In general, the disclosure of information to investors to strengthen market discipline is carried out more slowly than the regulation on financial disclosure. Currently, this study only considers listed banks, which are heavily regulated in terms of information disclosure regulations on the stock market, so it is expected that the performance of these banks will be better or must meet minimum disclosure requirements.

The banks almost comply with regulation on financial disclosure. Regarding to the Circular 41 regulated by Vietnam State Bank, the study team did not find any evidence relating to risk disclosure at the end of 2020 of 2 banks and 6-month updated risk information of some banks. The current status leads to an issue in supervision of the compliance with the Circular 41 which the State bank is facing. And how the unlisted commercial banks of May-May, 2021 which is earlier than due date for information disclosure. The research team has not yet collected evidence on the disclosure of updated information on capital adequacy ratio, operating risk, and liquidity risk for the remaining 4 listed banks.

comply with the Circular. The limitation of this study is the collection of data from information sources on the website of the bank, and the Stock Exchange. It is possible that banks make information disclosure at their headquarters (still meeting the requirements of Circular 41) and the research team was not able to access data from this channel. However, if this happens, it also shows the inadequacy of the listed bank's information disclosure efficiency. The extent and effectiveness of information disclosure reflects the efficiency and quality of banking governance. In addition, banks should put disclosure information that meets Circular 41 in a separate section on the website to make it easier for investors to find and access.

In addition to the limitation on accessing and collecting data, the method of building and calculating the index used in this study is quite simple and only takes into account whether or not information is disclosed, not considered about the quality of disclosure.

Circular 41 and Circular 13/2018/TT-NHNN have given full guidelines for commercial banks to apply Basel II and this is a challenge for many banks. However, after the global financial crisis of 2007-2008, the Basel Committee introduced the Basel III version to overcome the limitations in the financial regulatory framework in order to strengthen equity requirements, asset quality, and limit the bank's financial leverage. Basel III was introduced in 2010 and the application period has been adjusted several times, the latest adjustment being January 2023. Some domestic banks have also taken steps to prepare for the application of this Basel III standard such as Maritime Bank (MSB), International Bank (VIB) (Nhue Man, 2021). Thus, in order to support banks in Vietnam to continue implementing Basel III, the State Bank of Vietnam needs to provide guidance and support for commercial banks to implement this activity. 
Appendix 1

List of banks listed on the Stock Exchanges of Hanoi and Ho Chi Minh City

\begin{tabular}{|c|c|c|c|}
\hline No & Code & Name of Bank & $\begin{array}{l}\text { Basel II } \\
\text { Application }-1^{\text {st }} \\
\text { Pilot stage }\end{array}$ \\
\hline 1 & $\mathrm{ACB}$ & Asia Commercial Joint Stock Bank & $\mathrm{x}$ \\
\hline 2 & $\mathrm{BAB}$ & North Asia Commercial Joint Stock Bank & \\
\hline 3 & BID & $\begin{array}{l}\text { Joint Stock Commercial Bank for Investment and } \\
\text { Development of Vietnam }\end{array}$ & $\mathrm{x}$ \\
\hline 4 & CTG & $\begin{array}{l}\text { VietNam Joint Stock Commercial Bank for Industry and } \\
\text { Trade }\end{array}$ & $\mathrm{x}$ \\
\hline 5 & EIB & Vietnam Export Import Bank & \\
\hline 6 & HDB & $\begin{array}{l}\text { Ho Chi Minh City Development Joint Stock Commercial } \\
\text { Bank }\end{array}$ & \\
\hline 7 & LPB & LienVietPostBank & \\
\hline 8 & MBB & Military Commercial Joint Stock Bank & $\mathrm{x}$ \\
\hline 9 & MSB & The Maritime Commercial Joint Stock Bank & $\mathrm{x}$ \\
\hline 10 & NVB & National Citizen Commercial Joint Stock Bank & \\
\hline 11 & OCB & Orient Commercial Joint Stock Bank & \\
\hline 12 & SHB & SaiGon - HaNoi Commercial Joint Stock Bank & \\
\hline 13 & SSB & Southeast Asia Commercial Joint Stock Bank & \\
\hline 14 & STB & Sai Gon Thuong Tin Commercial Joint Stock Bank & $\mathrm{x}$ \\
\hline 15 & TCB & Technological and Commercial Join-stock Bank & $\mathrm{x}$ \\
\hline 16 & TPB & Tien phong Commercial Joint Stock Bank & \\
\hline 17 & VCB & $\begin{array}{l}\text { Joint Stock Commercial Bank for Foreign Trade of } \\
\text { Vietnam }\end{array}$ & $\underline{x}$ \\
\hline 18 & VIB & Vietnam International Commercial Joint Stock Bank & $\mathrm{x}$ \\
\hline 19 & VPB & Vietnam Prosperity Joint Stock Commercial Bank & $\mathrm{x}$ \\
\hline
\end{tabular}

Source: Study Team, 2021

\section{REFERENCES}

[1] Baumann, U. and; Nier, E. (2003), Market discipline and financial stability: some empirical evidence. Financial Industry and Regulation Division, Bank of England, Financial Stability Report.

[2] Botosan, C.A.(1997), "Disclosure level and the cost of equity capital", The Accounting Review 72 (3), 323-350.
[3] Duy Lap (2020), Vietinbank officially applied Circular 41/2016/TT-NHNN from January 1, 2021, thanhnien.vn accessed on August 24, 2021.

[4] Huang, Rocco (2006), Bank Disclosure Index: Global Assessment of Bank Disclosure Practices. Available SSRN: https://ssrn.com/abstract=1425915

[5] Hong Dung (2020), Considering extending the deadline for Basel II implementation, Tinhnhanhchungkhoan.vn accessed on August 24, 2020 
[6] LA and NT (2010), Basel Capital Accord (Basel I and II), accessed February 24, 2021 at: https://www.sbv.gov.vn/webcenter/portal/en/menu/ $\mathrm{fm} / \mathrm{ddnhnn} / \mathrm{nctd} / \mathrm{nctd}$ chitiet?centerWidth $=80 \% 25 \&$ dDocName=CNTHWEBAP01162524865...

[7] Minh Khoi (2019), Banking and Destination Basel II, accessed February 24, 2021 at: https://sbv.gov.vn/webcenter/portal/en/menu/trangc $\mathrm{hu} / \mathrm{ttsk} / \mathrm{ttsk}$ _chitiet? leftWidth $=20 \% 25 \&$ showFooter=false \&showHeader $=$ false $\&$ dDocName $=$ SBV401022...

[8] Nhue Man (2021), Basel II completed, Tinhnhanhchungkhoan.vn accessed on August 23, 2021.

[9] Patel, Sandeep A. and Dallas, George S., "Transparency and Disclosure: Overview of Methodology and Study Results - United States", Standard \& Poor's Publication, (October 16, 2002)

[10] Sengupta P. (1998), “Corporate Disclosure quality and the cost of debt", The Accounting Review, 73(4), pp. 459-474.

[11] State Bank of Vietnam (2016), Circular No. 41/2016/TT-NHNN - Regulations on capital adequacy ratio for banks and foreign bank branches.

[12] Basel Committee (2004), International Convergence of Capital Measurement and Capital Standards, A Revised Framework.

[13] Basel Committee (2010), Basel III Implementation, https://www.fsb.org/work-of-thefsb/implementation-monitoring/monitoring-ofpriority-areas/basel-iii/, access on 24/8/2021.

[14] Van Linh (2019), Basel II race hits the finish line, Tinhnhanhchungkhoan.vn accessed on August 24, 2021. 